LINGUISTIKA, MARET 2019

p-ISSN: 0854-9613

Vol. 26. No. 1

\title{
MAKNA EKOLOGI BUDAYA LEKSIKON PER-UNDAGI-AN BAHASA BALI
}

\author{
I Putu Permana Mahardika ${ }^{1}$, I Wayan Simpen ${ }^{2}$, Putu Sutama ${ }^{3}$ \\ Dinas Pendidikan Provinsi Bali ${ }^{1}$ \\ permanamahardika@gmail.com,wyn.simpen@gmail.com,pt_sutama@unud.ac.id \\ Fakultas Ilmu Budaya, Universitas Udayana ${ }^{2,3}$
}

\begin{abstract}
Abstrak-Penelitian ini mendeskripsikan makna ekologi yang terkandung dalam leksikon per-undagi-an bahasa Bali. Data diperoleh dengan menggunakan metode simak yang dibantu dengan teknik catat. Data yang dikumpulkan dianalisis dengan menerapkan teori ekolinguistik dan didukung oleh teori semiotik. Adapun leksikon per-undagi-an yang digunakan dalam penelitian ini, yaitu: (a) leksikon kayu, (b) leksikon batu, dan (c) leksikon kekarangan. Berdasarkan analisis yang dilakukan, ditemukan bahwa leksikon per-undagi-an memiliki makna ekologi yang didasari karya-karya sastra Hindu, seperti, Aji Janāntaka, Asta Kosali, Asta Bhumi, dan Kekawin Bhomāntaka.
\end{abstract}

Kata kunci: ekolinguistik, makna ekologi, leksikon per-undagi-an

Abstract--This research aims at describing the ecological meaning based on undagies lexicon in Balinese. The data collected by direct observation and combined with note-taking. The collected data was analyzed by applying the theory of ecolinguistics and semiotic. The lexicon used in this research were; (a) wood lexicon; (b) stone lexicon; and (c) kekarangan lexicon. Based on the analysis conducted, it was found that the undagies lexicon has an ecological meaning based on Hindus literaries such as; Aji Janāntaka, Asta Kosali, Asta Bhumi, and Kekawin Bhomāntaka.

Keywords: ecolinguistics, ecological meaning, undagies lexicon 


\section{PENDAHULUAN}

Kebudayaan suatu guyub tutur dapat diketahui karena realitas kebudayaan yang dilambangkan, diwujudkan, dan diungkapkan ke dalam sebuah bahasa sehingga kekayaan dan kekhasan sebuah kebudayaan akan tercermin dalam leksikon. Sebagai salah satu bahasa, bahasa Bali mengenal berbagai jenis leksikon. Salah satu di antaranya adalah leksikon perundagi-an. Berkaitan dengan lingkungan, bahasa Bali (BB) memiliki sangat banyak leksikon yang berkaitan dengan per-undagi-an (arsitektur tradisinonal Bali), khususnya pada arsitektur bangunan tradisional Bali. Untuk mempelajari cara pembuatan bangunan tradisional, paling tidak harus diketahui pedoman (sastra) yang digunakan dalam mendirikan suatu bangunan, seperti Asta Kosali, Asta Bhumi, dan Aji Janāntaka. Dengan demikian, bangunan yang dibentuk sesuai dengan kegunaan atau fungsinya, akan dibuat sesuai dengan petunjuk-petunjuk yang termuat dalam naskah-naskah lontar tersebut (Nadia dan Prastika, 2009: 7).

Adapun pembahasan makna ekologi leksikon per-undagi-an difokuskan pada makna budaya yang terkandung dalam leksikon perundagi-an, khususnya leksikon-leksikon tentang lingkungan.

\section{METODE PENELITIAN}

Data yang digunakan dalam penelitian ini bersumber pada tuturan lisan dan teks-teks tertulis. Teks-teks tertulis tersebut di antaranya
Asta Kosali, Asta Bhumi, dan Aji Janāntaka. Metode yang diterapkan pada penelitian ini melalui tiga tahapan, yaitu (a) pengumpulan data, (b) analisis data, dan (c) penyajian hasil analisis data. Pada tahap penyediaan data digunakan dua metode, yaitu metode simak dan metode cakap. Metode simak dalam penelitian ini dibantu dengan teknik dasar sadap dan teknik lanjutan, yaitu teknik simak bebas libat cakap dan teknik tulis. Selanjutnya pada metode cakap, teknik dasar yang digunakan, yaitu teknik pancing dan teknik lanjutan cakap semuka. Sementara itu, pada tahap analisis data digunakan metode padan dan metode agih. Metode padan yang digunakan dalam menganalis data penelitian ini adalah metode padan referensial dengan teknik dasar, yaitu teknik pilah unsur penentu (PUP). Selanjutnya, pada metode agih digunakan teknik bagi unsur langsung (BUL) sebagai teknik dasar. Pada tahap penyajian hasil analisis data digunakan metode formal dan informal.

Adapun teori payung yang digunakan dalam penelitian ini adalah teori ekolinguistik. Teori ekolinguistik merupakan salah satu perspektif linguistik yang mengkaji bahasa secara makro, yang bersifat lintas bidang, kajian yang interdisipliner. Ekolinguistik mengkaji bahasabahasa dalam suatu sudut pandang yang terbuka dan tertentu, sebagai suatu ekosistem kebahasaan, perspektifnya lebih menyeluruh dalam memandang bahasa atau bahasa-bahasa yang hidup dalam suatu kawasan.

Selain menggunakan teori ekolinguistik, penelitian ini juga dibantu dengan teori 
semiotik. Teori semiotik digunakan untuk melihat makna-makna ekologi yang terkandung dalam leksikon-leksikon per-undagi-an

\section{PEMBAHASAN}

\section{Leksikon tentang lingkungan yang} ditetapkan dalam penelitian ini, yaitu (a) leksikon jenis kayu, (b) leksikon jenis batu, dan (c) leksikon jenis kekarangan. Secara lebih terperinci, makna leksikon per-undagi-an tersebut disajikan di bawah ini.

\section{A) Makna Budaya Leksikon Kayu}

Kayu ${ }^{1}$ merupakan salah satu bahan bangunan utama yang digunakan dalam pembuatan rumah tradisional Bali. Hampir semua tipologi bangunan Bali menggunakan kayu sebagai tiang dan kerangka atap. Kayu merupakan bahan bangunan yang dapat diperbarui, karena kayu dapat ditanam dan dipelihara. Di samping itu, jika sudah cukup umurnya, kayu dapat ditebang untuk keperluan bahan bangunan.

Kayu yang digunakan dalam mendirikan bangunan tradisional Bali banyak termuat pada teks Aji Janāntaka ${ }^{2}$, seperti kayu cendana, majagau, kaliasem, kwanditan, dan taru sari. Di

\footnotetext{
${ }^{1}$ Menurut lontar Asta Kosala Kosali yang telah dialihaksarakan dan diterjemahkan oleh Ida Nyoman Bodha dari Griya Jlantik Balér Margi Subagan, kayu berasal dari kata $\mathrm{Ka}$ 'wit, asal' dan $Y u$ 'Buddha, yaitu budi dan pikiran'.

2 Aji Janāntaka merupakan salah satu teks tutur (ajaran) dalam klasifikasi naskah Bali. Kata Aji lebih mengacu pada ajaran atau ilmu, yang memuat klasifikasi kayu (Suardiana, 2017).
}

antara leksikon-leksikon yang tergolong dalam klasifikasi ${ }^{3}$ kayu, leksikon cendana 'cendana' dan majagau 'majagahu' tampak dominan digunakan oleh masyarakat Bali sebagai bahan pembuatan tempat suci. Leksikon cendana dan majagau bagi masyarakat Bali termasuk jenis kayu (pohon) yang utama. Kedua jenis kayu ini tergolong kayu merik atau kayu yang berbau harum. Ke-utama-an inilah menyebabkan kedua jenis kayu ini menurut teks Aji Janāntaka diklasifikasikan sebagai kayu Prabhu 'raja kayu'. Selain itu, menurut teks, kayu cendana ${ }^{4}$ merupakan salah satu perwujudan ${ }^{5}$ kesadaran Siwa, yaitu Parama Siwa, dan oleh Rsi Wita Dharma kayu tersebut diberikan gelar Brahmana Kemenuh, sedangkan kayu majagau ${ }^{6}$ merupakan perwujudan Siwa, yaitu Sadasiwa dan diberi gelar Brahmana Geniten.

\footnotetext{
${ }^{3}$ Dalam teks Aji Janāntaka terdapat klasifikasi jabatan si kayu (pohon) ketika mereka masih hidup sebagai manusia, sebagaimana kisah Prabhu Partipa dari Janāntaka, yaitu (a) prabhu, (b) patih, (c) arya, (d) rangga, (e) demung, (f) demang, (g) tumenggung, (h) pecalang, (i) prebekel, (j) klian, (k) kasinoman, (1) juru arah, dan $(\mathrm{m})$ raréncék.

${ }^{4}$ Berasal dari kata ca 'mata' (caksu) yang juga disebut dengan surya. Sur 'niskala' dan Ya 'sekala'. Dengan demikian, cendana dapat dikatakan sebagai perwujudan dewa dalam kenyataan.

${ }^{5}$ Dalam teks Aji Janāntaka terdapat tiga kayu yang dianggap sebagai perwujudan Siwa, yaitu kayu cendana sebagai Parama Siwa, majagau sebagai Sadasiwa, dan cempaka putih sebagai Siwa Sejati.

${ }^{6}$ Berasal dari kata maja 'bayu', ga 'badan', dan $u$ 'Brahma' sehingga dapat dartikan sebagai badan yang memiliki kekuatan Dewa Brahma.
} 
Vol. 26. No. 1

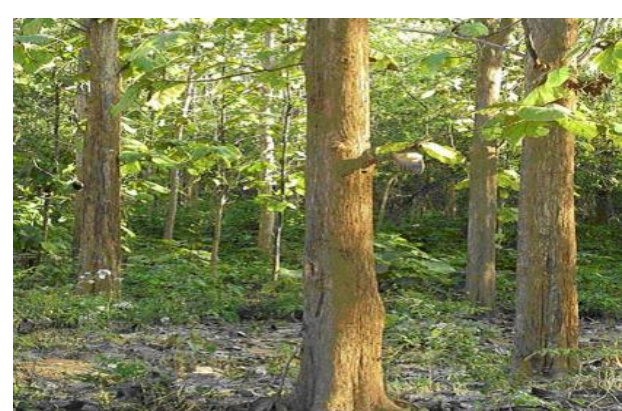

Gambar 1, Kayu Cendana

Sumber: https://manfaat.co.id/9-manfaat-kayucendana-bagi-kehidupan-manusia

Adanya gelar kayu prabhu untuk kayu cendana menyebabkan jenis kayu ini dapat digunakan sebagai bahan utama untuk pembuatan pratima, pralingga 'perwujudan fisikal Tuhan atau berbagai dewa dalam agama Hindu'. Di samping itu, masih kaitannya dengan sarana upacara, kayu cendana dan majagau dapat digunakan sebagai sarana untuk pembuatan pasepan atau dupa. Serbuk kayu cendana dan majagau yang wangi juga dapat digunakan dalam pembuatan basma (Yasa, 2017: 323).

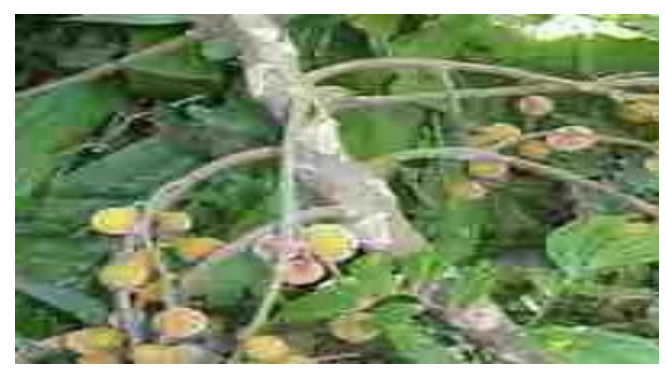

Gambar 5.21 Kayu Majagau

Sumber:

https://www.biodiversitywarriors.org/isikatalog.php?idk=5613

\section{B) Makna Budaya Leksikon Batu}

Batu merupakan salah satu material yang paling banyak digunakan dalam pembuatan atau pendirian suatu bangunan, baik sebagai fondasi maupun sebagai dekorasi. Di antara leksikonleksikon yang tergolong dalam leksikon batu, leksikon batu bata merupakan jenis batu yang sering digunakan. Batu bata merupakan material modular yang dihasilkan dari pembakaran tanah liat. Karena dihasilkan dari proses pembakaran tanah liat, masyarakat mengenal jenis batu bata, yaitu batu bata Jematang yang berwarna lebih tua atau batu bata Tulikup dengan warna merah lebih terang.

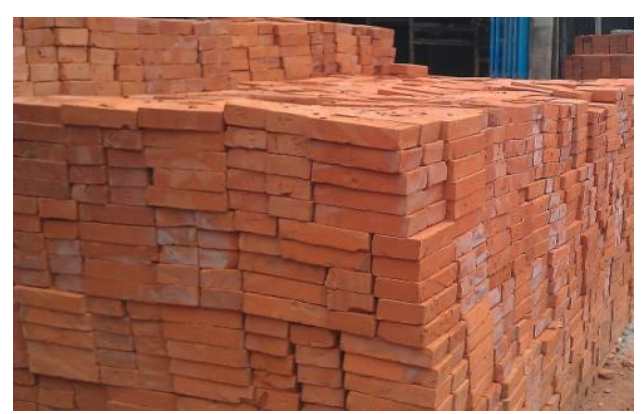

Gambar 3, Batu Bata

Sumber:

http://batubatajonegoro.blogspot.com/2017/06/ap a-itu-batu-bata.html

Batu bata memiliki karakteristik tertentu, yaitu getas 'mudah patah/ pecah', parus 'berpori', dan berwarna merah. Penggunaan batu bata pada langgam arsitektur tradisional Bali sangat jelas tampak pada arsitektur Bali langgam Bebadungan. Dalam konteks arsitektur, kata Bebadungan sering digunakan untuk menyatakan bentuk arsitektur yang banyak berkembang di wilayah Badung-Denpasar yang dominan menggunakan material batu bata (Siwalatri, 2015: 40--42)

Batu bata dianggap memiliki banyak kegunaan oleh masyarakat. Adapun salah satu 
Vol. 26. No. 1

kegunaan batu bata dalam arsitektur tradisional Bali adalah sebagai sarana pada upacara nasarin $^{7}$ 'peletakan batu pertama' yang di atasnya digambar Bhadawangnala yang ditanam di bawah sesaka yang akan dijadikan tempat pokok upacara pemakuhan.

\section{C) Makna Budaya Leksikon Kekarangan}

Kekarangan merupakan ragam hias yang menampilkan suatu bentuk hiasan dengan suatu karangan atau rancangan yang berusaha mendekati bentuk-bentuk flora yang ada dengan penekanan pada bagian-bagian keindahan (Gelebet, 2002: 332). Salah satu ragam kekarangan yang sering dijumpai adalah karang bhoma. Karang Bhoma ${ }^{8}$ merupakan ukiran yang berbentuk kepala raksasa yang dilukiskan dari leher ke atas lengkap dengan hiasan dan mahkota yang diturunkan dari cerita Bhomāntaka (Gelebet, 2002: 359). Umumnya ukiran Karang Bhoma ditempatkan di atas pintu masuk atau

\footnotetext{
${ }^{7}$ Pada upacara ngeruwak, ngendag/nasarin 'peletakan batu pertama' digunakan batu bata merah yang digambari Bhadawangnala (simbol dasar dunia) dan ditulisi aksara $A N G$ pada bagian punggung (Nadia dan Prastika, 2009: 85).

8 Hiasan yang diambil dari cerita Jawa Kuno (Kekawin) Bhomāntaka atau Bhomakawya 'kematian Sang Bhoma' yang berisi tentang peperangan antara Prabhu Krsna dan Sang Bhoma; yang merupakan putra Déwa Wisnu dengan Déwi Pertiwi sehingga Bhoma sering juga disebut dengan Putra Bumi. Jika dilihat secara etimologi berasal dari bahasa Sanskerta Bhaumā 'sesuatu yang tumbuh atau sesuatu yang lahir atau berhubungan dengan bumi'. Di samping itu, juga memiliki kaitan dengan konsepsi Hindu India yaitu kīrthimukha. Di Jawa Timur Bhoma dikenal sebagai bentuk Banaspati pada arsitektur candi. Oleh karena itu, Bhoma dalam ornamen di atas lubang pintu kori agung dimaknai sebagai penjaga kesakralan bangunan suci di Bali (Titib, 1983).
}

biasa disebut dengan candi kurung (lambang Gunung Mahameru). Dalam kekawin Bhomāntaka disebutkan bahwa Bhoma merupakan putra Dewa Wisnu dan Dewi Pertiwi, ketika Dewa Wisnu menjelma menjadi Waraha 'babi hutan' untuk menuju pangkal lingga ke bawah, yaitu perut bumi. Ketika Dewa Wisnu menggali menuju pangkal lingga-lah bertemu dengan Dewi Pertiwi. Pertemuan Dewi Pertiwi dan Dewa Wisnu kemudian berlanjut sebagai kisah percintaan yang kemudian melahirkan seorang putra, yang bernama Bhoma.

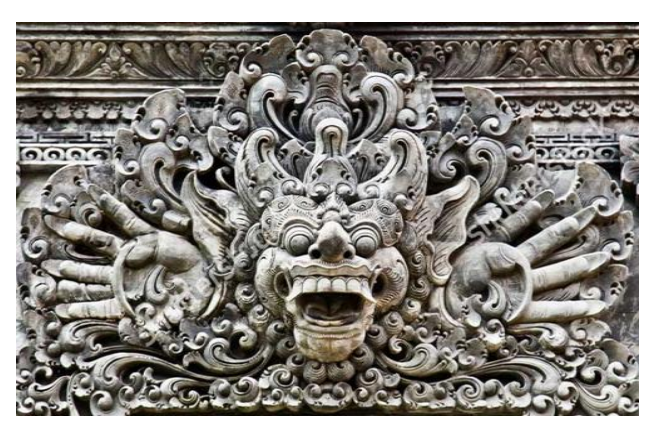

Gambar 4, Karang Bhoma

Sumber: http://www.ukirbali.net/2018/04/jenismotif-kekarangan-karya-seni.html

Pertemuan antara Dewa Wisnu dalam manifestasinya sebagai Waraha 'babi hutan' dengan Dewi Pertiwi dalam konteks lingkungan dapat diumpamakan sebagai air yang meresap ke dalam bumi, yang kemudian melahirkan sebuah kehidupan. Lebih lanjut, adapun fungsi Karang Bhoma pada candi kurung adalah sebagai media panglukatan 'meruwat' karena ketika seseorang memasuki pura secara tidak langsung akan diruwat atau disucikan oleh Karang Bhoma.

Selain Karang Bhoma, terdapat pula jenis kekarangan yang sering dijumpai, yaitu Karang 
Asti. Karang Asti merupakan ukiran berbentuk kepala gajah, yang diletakkan pada bagian bawah dengan pertimbangan bahwa gajah merupakan binatang besar yang kuat sehingga gajah dianggap mampu menyangga bangunan dengan baik. Selain itu pemilihan Karang Asti berada pada bagian bawah bangunan juga disesuaikan dengan tempat hidup hewan yang dijadikan bentuk (tempat hidup gajah berada di tanah).

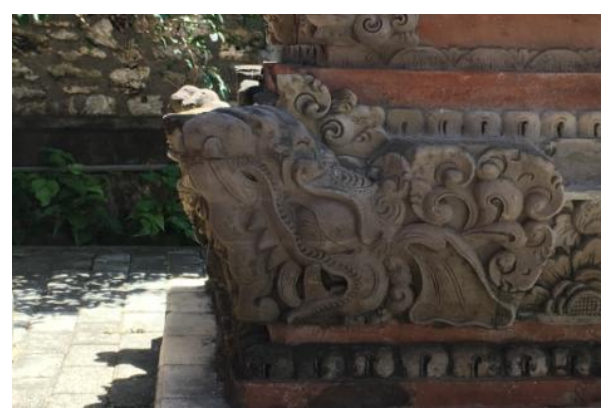

Gambar 5, Karang Asti/ Karang Gajah Sumber: Permana Mahardika (2018)

Adapun dalam konteks kebudayaan Bali, makna Karang Asti sebagai cerminan bahwa seseorang harus astiti 'bakti/ berbakti' terhadap segala kekuatan yang ada dan bersungguhsungguh ketika manusia mendekatkan diri dengan Sang Pencipta (melaksanakan Yoga Semadi), yang diibaratkan seperti seekor gajah (yang mampu menerjang segala rintangan sehingga gajah dianggap sebagai seekor binatang yang kuat).

\section{SIMPULAN}

Berdasarkan hasil analisis di atas, penelitian dengan menggunakan pendekatan ekolinguistik yang dipadukan dengan semiotik mampu menguraikan makna ekologi yang terkandung dalam leksikon. Makna-makna ekologi tersebut didasari ajaran-ajaran agama Hindu yang terkandung dalam karya-karya sastra sehingga makna ekologi yang terkandung merefleksikan adanya interaksi penutur bahasa Bali dengan leksikon per-undagi-an beserta entitasnya.

\section{DAFTAR PUSTAKA}

Fill, Alwin \& Mühlhäusler Peter. 2001. The Ecolinguistics Reader: Language, Ecology, and Environment. London: Continuum.

Gelebet, I Nyoman dkk. 2002. Arsitektur Tradisional Bali. Badan Pengembangan Kebudayaan dan Pariwisata: Deputi Bidang Pelestarian dan Pengembangan Budaya Bagian Proyek Pengkajian dan Pemanfaatan Sejarah dan Tradisi Bali.

Hoed, Benny H. 2008. Semiotik dan Dinamika Sosial Budaya. Jakarta: Komunitas Bambu.

Nadia, I Ketut \& I Nyoman Prastika. 2008. Arsitektur Tradisional Bali. Denpasar: Widya Dharma.

Renjaan, Meiksyana Raynold. Leksikon Bahasa Kei dalam Lingkungan Kelautan: Kajian Ekolinguistik. Linguistika: Buletin Ilmiah Program Magister Linguistik Universitas Udayana, [S.1.], v. 21, sep. 2014. ISSN 0854-9613. Available at: <https://ojs.unud.ac.id/index.php/linguistik a/article/view/21891>. Date accessed: 28 dec. 2018.

Siwalatri, Ni Ketut Ayu. 2015. Bebadungan dan Identitas Kota di Bali. Denpasar: IAI Bali.

Suardiana, I Wayan. 2014. "Klasifikasi Pepohonan dan Kegunaannya serta Pelestarian Lingkungan dalam Teks Aji Janantaka". Simposium Internasional Pernaskahan Sunda.

Sudaryanto. 2015. Metode dan Aneka Teknik Analisis Bahasa: Pengantar Penelitian Wahana Kebudayaan secara Linguistis. Yogyakarta: Sanata Dharma University Press.

Suweta, I Made. 2013. Ecolinguistics Approach in Preservation Rare Plants Growing in 
Bali. International Journal of Linguistics Vol. 5, No. 1. Macrothink Institute.

Tangkas, Made Reland Udayana. "Tuturan Majejiwan dalam Ritual Mapaselang di Bali: Kajian Linguistik Kebudayaan ". Linguistika: Buletin Ilmiah Program Magister Linguistik Universitas Udayana, [S.1.], v. 22, jan. 2015. ISSN 0854-9613. Available at: <https://ojs.unud.ac.id/index.php/linguistik a/article/view/13998>. Date accessed: 28 dec. 2018.

Titib, I Made. 1983. Arti dan Fungsi Bhoma pada Kori Agung di Bali. Denpasar: Institut Hindu Dharma.

Yasa, Putu Eka Guna. 2017. Evolusi Fonologis dan Makna Budaya Leksikon dalam Bahasa Bali. Denpasar: Universitas Udayana. 